\title{
EFFECT OF SOME STIMULANTS ON FRUIT SET, YIELD AND FRUIT QUALITY OF HOLLYWOOD AND PIONEER PLUM CULTIVARS
}

\author{
AZZA I. MOHAMED; A. ABD EL BARY and M. A. FATHI \\ Deciduous Fruit Res. Department, Horticulture Research Institute, ARC, Giza, Egypt.
}

(Manuscript received 3 April 2018)

\begin{abstract}
$\mathrm{T}$ he deterioration in area of plum orchards, in addition to the lack of productivity resulted in an insufficient yield of plum. Some stimulants were investigated in this study during 2016 and 2017 seasons to improve fruit set; yield and fruit quality of Hollywood and Pioneer plum cultivars. Trees were treated with sprayed by with 1.0 and $1.5 \mathrm{ml} / \mathrm{l}$ of Daiblon $\mathrm{k} 10$ (contains $10 \%$ $\mathrm{w} / \mathrm{w}$ free amino acids and $10 \% \mathrm{w} / \mathrm{w}$ potassium) or 4.0 and $6.0 \mathrm{ml} / \mathrm{l}$ of Essential Egy (contains mineral nutrients; natural Organic substance and $4.5 \%$ L-amino acids). Other trees were treated with Humic acid as Actosol ${ }^{\circ}(6.0 \% \mathrm{w} / \mathrm{v}$ potash and $20 \% \mathrm{w} / \mathrm{v}$ Humate) at $5.0 \mathrm{ml} / \mathrm{l} /$ tree as spray foliar treatment or $30 \mathrm{ml} / \mathrm{l} /$ tree as soil application beside (control). The treatments were done at three times (at $30 \%$ of flowering; 70\% flowering and at full bloom) in each season. All trees were grown in a sandy soil at ElNubaria region, Behera Governorate, Egypt. A complete randomized block design was used with three replicates and each one was represented by one tree. During this investigation fruit set (\%); yield (kg/tree); some physical and chemical fruit properties as well as some mineral contents of leaves were determined. Results cleared that the highest of both fruit number and yield $(\mathrm{Kg} / \mathrm{tree})$ were obtained when trees of Hollywood were sprayed with Essential Egy at $4.0 \mathrm{ml} / \mathrm{l}$ while the highest values of fruit set $\%$ and SSC were gained when trees were sprayed with $6.0 \mathrm{ml} / \mathrm{l}$ of Essential Egy. Spraying trees with Humic acid caused the highest leaf $\mathrm{N}$ and $\mathrm{K}$ content. All treatments under study gave variable effects on of total chlorophyll content. With regard to Pioneer cultivar, results showed that Essential Egy at $6.0 \mathrm{ml} / \mathrm{l}$ significantly increased fruit set \%; fruit number per tree, yield $(\mathrm{kg} /$ tree and $P$ content compared with Essential Egy at $0.4 \mathrm{ml} / \mathrm{l}$ which significantly increased SSC. Humic acid soil application significantly increased leaf $\mathrm{N}$ and $\mathrm{P}$ content. Spraying trees with Humic acid recorded the highest significant $\mathrm{N}$ and $\mathrm{K}$ content. Daiblon $\mathrm{K} 10$ at $1.0 \mathrm{ml} / \mathrm{l}$ gave the maximum total chlorophyll content. Thus, it can be recommended that spraying Hollywood and Pioneer cultivars with Essential Egy at $4.0 \mathrm{ml} / \mathrm{l}$ or $6.0 \mathrm{ml} / \mathrm{l}$ at three times $(30 \%$ of flowering; $70 \%$ of flowering and at the full bloom) will increase plum yield and improve fruit quality.
\end{abstract}

Key words: Plum, Hollywood and Pioneer cultivars, Bio stimulants, Daiblon K10, Essential Egy, Humic acid.

Abbreviation : SSC $=$ Soluble solides content. 


\section{INTRODUCTION}

Plum (prunus salicina L.) is a popular fruit and considered of the important fruits in the world. Since the total area of plum in Egypt reached about 2614 feddans according to the census of the Ministry of Agriculture, Egypt 2015 which produced 13941 tons, with average yield of 5.637 tons /fed. The deterioration in area of plum orchards, in addition to the lack of productivity resulted in an insufficient yield of plum.

In recent years, there have been growing interests in the use of bio-stimulants to improve fruit set, yield and quality of fruit. Bio-stimulants are known as the organic materials which promote plant growth and help plants to withstand harsh environments when applied in small quantities (Chen et al., 1994).In recent years, growers exhibited in the use of bio-stimulants to improve yield and fruit quality in horticultural crops. Among the bio-stimulants tried were natural organic substances, mineral nutrients, amino acid and Humates. Spraying trees with liquid organic fertilizers seemed to be promised increase fruit set, yield and fruit quality of plum. The mode of action for micro- elements were explained by Larue and Johnson (1989).

Amino acids have a chelating effect on micro nutrients when applied together, where the absorption and transportation of micro nutrients inside the plant is easier. This effect is due to the chelating action, the effect of cell membrane permeability and low molecular weight (Westwood 1993).Also, amino acids (as organic nitrogenous ) are well known to stimulate cell growth and to act as buffers, maintaining favorable $\mathrm{PH}$ value within the plant cell, as well as synthesizing other organic compounds (Opike and Rolfe, 2005).

Humates are the salts of Humic acids (HAs). HAs are complex molecules formed by the breakdown of organic matter (Swietlik, 1991). Likewise, Fayed (2010) indicated that Humic acid ( $\mathrm{HA})$ is a heterogeneous mixture of many compounds with generally similar chemical properties which performs various functions in the soil and on plant growth. Hence, iron - Humate significantly increased orange and grapefruit trees growth and fruit production (Alva and Obrea, 1998).

Therefore, this study was conducted to investigate the response of Hollywood and Pioneer plum cultivars to different concentrations of foliar spraying of biostimulants i.e. DaiblonK10; Essential Egy; foliar and soil application of Humic acids on fruit set, yield and fruit quality.

\section{MATERIALS AND METHODS}

This investigation was conducted during the 2016 and 2017 seasons in a private orchard at El-Nubaria region, Behera Governorate, Egypt. Five-years-old 
Hollywood and Pioneer plum trees budded on Mariana rootstock, planted at $4 \times 5 \mathrm{~m}$, grown in a sandy soil under drip irrigation system were chosen. Healthy and as uniform as possible were selected to perform this study.

Trees were treated with the following treatments:-

T1:-Daiblon K10 [D.] foliar spray at $1.0 \mathrm{ml} / \mathrm{L}$.

T2:-Daiblon K10 [D.] foliar spray at $1.5 \mathrm{ml} / \mathrm{L}$.

\{DaiblonK10:-A commercial product contains 10\% w/w free amino acids and $10 \% \mathrm{w} / \mathrm{w}$ potassium $(\mathrm{pH} 10.4)\}$.

T3:-Essential Egy [E.] foliar spray at $4.0 \mathrm{ml} / \mathrm{L}$.

T4:- Essential Egy [E.] foliar spray at $6.0 \mathrm{ml} / \mathrm{L}$.

\{Esssential Egy: -A commercial product contains mineral nutrients; natural organic substances and $4.5 \%$ L-Amino acids\}.

T5:-Humic acid [H.] soil application at $30 \mathrm{ml} / \mathrm{I} /$ tree.

T6:-Humicacid [H.] foliar spray at $5.0 \mathrm{ml} / \mathrm{L}$.

\{Humic acid (Actosol):-A commercial product contains potash $6.0 \%$

$(\mathrm{w} / \mathrm{v})$ and Humate (chelator) $20 \%(\mathrm{w} / \mathrm{v})\}$.

T7:- Control [tap water].

At $30 \% ; 70 \%$ of flowering and full bloom. Statistically, a complete randomized block design was used with three replicates each represented by one tree. Data obtained were statistically analyzed using the analysis of variance method reported by Snedecore and Cochran (1990) and the differences were tested by Duncan (1955) at a probability of $5 \%$.

\section{The following measurements were carried out: -}

\subsection{Flowering and Fruiting :-}

Twenty five spurs were labeled and selected on each tree of each cultivar to determine the date of bud swelling, complete flowering and fruit set.

Table 1. Dates of different stages of flower bud opening till fruit set of the two plum cultivars in 2016 and 2017 seasons.

\begin{tabular}{|l|c|c|c|}
\hline \multirow{2}{*}{ Cultivar } & \multicolumn{3}{|c|}{ First season: 2016 } \\
\cline { 2 - 4 } & \multicolumn{3}{|c|}{ Different stages of flower bud opening } \\
\cline { 2 - 4 } & Bud swell & Complete flowering & Fruit set \\
\hline Hollywood & Feb.18 & Mar.3 & Mar.10 \\
\hline Pioneer & Feb.12 & Feb.28 & Mar.5 \\
\hline \multicolumn{4}{|c|}{ Second season: 2017 } \\
\hline Hollywood & Feb.19 & Mar.7 & Mar.9 \\
\hline Pioneer & Feb.14 & Mar. 2 & Mar.5 \\
\hline
\end{tabular}


2.1.1 Percentage of flower bud openings:-

Percentage of flower bud opening were recorded and determined at the complete flowering (full bloom) of each cultivar and calculated according to the following equation:-

$$
\text { Percentage of flower bud opening }=\frac{\text { Number of opened flower bud }}{\text { Total number of flower bud }} \times 100
$$

It should be pointed out that total number of flower buds was counted when buds took the dome shape.

2.1. 2. Fruit set percentage:

Fruit set was determined by counting number of set fruits (after 30 days of full bloom). Percentage of fruit set of each cultivar was calculated as follows:

$$
\text { Fruit set }(\%)=\frac{\text { Number of set fruits }}{\text { Total number of flowers at full bloom }} \times 100
$$

\subsection{Yield:-}

At harvest time of each cultivar \{with Hollywood (May 18 and May 22) and with Pioneer (May 25 and May 27) in the first and second seasons, respectively\}, the total number of fruits per tree was counted and yield ( $\mathrm{Kg} /$ tree ) was estimated by multiplying number of fruit by average weight of fruit.

\subsection{Fruit properties:-}

At harvest time of each cultivar, a sample of 25 fruits per tree was taken for determining the following physical and chemical properties; fruit volume, weight, polar and equatorial diameters (equatorial diameter for the largest fruit width).Fruit firmness was recorded by Magness - Taylor type pressure tester that has a standard $7 / 16$ of inch ${ }^{2}$ plunger, and reading were recorded in / inch². Juice soluble solids content (SSC) was determined by using a hand refractometer. Total acidity percentage (expressed malic acid) and SSC/ TA ratio were estimated according to (A.O.A.C., 1990).

\subsection{Vegetative growth:-}

\subsubsection{Leaf total chlorophyll content:}

In mid-August of both seasons, total chlorophyll content (of the fourth leaf from shoot tip) was recorded in leaves using a SPAD 502 chlorophyll meter (Minolta corporation, Ramsew N.J. USA) as an indicative chlorophyll reading according to (Yadava 1986).

\subsubsection{Chemical determination:}

Thirty mature leaves taken from mid -shoot were collected at mid-August at of both seasons to determine. Leaf mineral content, nitrogen was estimated by microkjeldahalGunging method as described by Plummer (1971). Phosphorus was 
determined with a colorimetric method as described by Jackson (1958). Potassium was determined by flame photometer model E.E.L.as described by (Piper, 1950).

\section{RESULTS AND DISCUSSION}

\subsection{Flowering and Fruiting :-}

\subsection{Percentage of flower bud opening:}

Data in table (2) cleared that spraying Hollywood cultivar with Essential Egy bio stimulant at $6.0 \mathrm{ml} / \mathrm{l}$ gave the highest percentages of flower bud opening in the first season while $4.0 \mathrm{ml} / \mathrm{l}$ was the best in the second one, compared with other treatments. Daiblon $\mathrm{K} 10$ at $1.0 \mathrm{ml} / \mathrm{t}$ treatment which gained the minimum percentage in the two seasons under study. Meanwhile, with Pioneer plum cultivar, Daiblon K10 at $1.0 \mathrm{ml} /$ s significantly increased possessed the highest percentage of flower bud opening in the two seasons compared with Humic acid soil application which gained the lowest percentage in the first season, while spraying trees with either Essential Egy at $6.0 \mathrm{ml} / \mathrm{l}$; Humic acid at $5 \mathrm{ml} / \mathrm{l}$ or control possessed the lowest percentages in the second season.

These results are in harmony with, Makled and Ismaile (2016) who found that Pioneer cultivar possessed the highest percentage of flower bud opening (83.68\% and $83.31 \%$ ) in the two seasons. Furthermore, Karima and Abd-Wahed(2005) stated that using amino acids led to significant increases in number and diameter of flower of Matricaria chamomilla plant.

\subsubsection{Fruit set Percentage:}

Data in table (2) showed that spraying Hollywood cultivar with Essential Egy at $6.0 \mathrm{ml} / \mathrm{I}$ in the first season and Essential Egy at 4.0 and $6.0 \mathrm{ml} / \mathrm{l}$ in the second season gave the highest significant increase in fruit set percentages compared with other treatments including control which possessed the lowest significant values in the two seasons.

With respect to Pioneer cultivar, spraying trees with Essential Egy at $6.0 \mathrm{ml} / \mathrm{I}$ produced the maximum significant increase fruit set percentage compared with the other treatment including control which had the lowest significant values in the two seasons.

These results may be supported by the findings of Hassan et al., (2010) mentioned that Aminofert (20\% Amino acids, $12 \%$ organic acids and $5.6 \%$ chelated micro-elements) increased significantly fruit set in Hollywood plum cultivar as compared to the control. Similarly, mentioned Naiema (2008) found that Aminofert increased significantly fruit set on Le Conte pear trees. Positive effects of amino acid foliar spray applications could be attributed to enhancing pollen tube ovule 
penetration and delaying ovule senescence which increases fruit set and yield (Franco - Mora, 2005). Moreover, Abd Elaziz et al., (2017) referred that Pioneer cultivar had higher degree of partial self- incompatibility than Hollywood cultivar. So, the need additional cultivars as pollinators for good growing and fruiting. Thereof, Makled and Ismaile (2016) found that without any treatment percentage of both initial and final fruit set percentage were recorded in Pioneer cultivar $(75.70 \%, 69.10 \%$ and $8.16 \%$, $7.75 \%)$ in the two seasons.

\subsection{Yield:}

\subsubsection{Fruit number per tree and yield $(\mathrm{Kg} /$ tree):}

Data in table (2) showed that spraying Hollywood cultivar trees with Essential Egy at $4.0 \mathrm{ml} / \mathrm{I}$ gave the highest significant values of fruit number per tree and yield (Kg/tree) ,compared with other treatments including control which gained the lowest significant values in the two seasons.

On the other hand, spraying Pioneer cultivar with Essential Egy at $6.0 \mathrm{ml} / /$ gave the maximum significant increase in number of fruit per tree and yield ( $\mathrm{kg} / \mathrm{tree}$ ) compared with other treatments including control which possessed the two seasons. The control treatment had the lowest significant number of fruits per tree in the first and the second seasons.

These results are in agreement with those found by Hassan et al., (2010) found that foliar sprays with Aminofert increased significantly the yield of Hollywood plum cultivar as compared to the control. Furthermore, Naiema (2008) reported that Aminofert increased significantly the yield of Le Conte peer trees compared with control . Shahin et al., (2015) concluded that humic acid soil application at $150 \mathrm{~cm}^{3}$ per tree (once at full bloom) gained the highest yield ( $\mathrm{kg} / \mathrm{tree}$ ) of Kalamata olive trees. Moreover, Maklad and Ismaile (2016) who stated that Pioneer plum cultivar has high yield and early fruit ripening. 
Table 2. percentage of flower bud opening ; fruit set percentage and yield/ tree of two plum cultivars as affected by different stimulants in 2016 and 2017 seasons.

\begin{tabular}{|c|c|c|c|c|c|}
\hline \multirow{4}{*}{ Cultivar } & \multirow{4}{*}{ Treatments } & \multicolumn{4}{|c|}{ First season: 2016} \\
\hline & & \multicolumn{4}{|c|}{ Flowering and fruiting parameters } \\
\hline & & \multirow{2}{*}{$\begin{array}{c}\text { Flower bud } \\
\text { openings (\%) }\end{array}$} & \multirow{2}{*}{$\begin{array}{c}\text { Fruit set } \\
(\%)\end{array}$} & \multicolumn{2}{|c|}{ Yield } \\
\hline & & & & (No of fruit/tree) & $(\mathrm{Kg} /$ tree $)$ \\
\hline \multirow{7}{*}{ Hollywood } & D $1.0 \mathrm{ml} / \mathrm{L}$ & $64.29 \mathrm{~d}$ & $5.53 d$ & $400.7 \mathrm{e}$ & $15.91 \mathrm{~d}$ \\
\hline & D $1.5 \mathrm{ml} / \mathrm{L}$ & $76.39 \mathrm{c}$ & $6.30 \mathrm{c}$ & $411.0 \mathrm{~cd}$ & $15.12 \mathrm{e}$ \\
\hline & $\mathrm{E} 4.0 \mathrm{ml} / \mathrm{L}$ & $86.45 \mathrm{a}$ & $7.23 b$ & $459.3 \mathrm{~b}$ & $20.23 \mathrm{a}$ \\
\hline & $\mathrm{E} 6.0 \mathrm{ml} / \mathrm{L}$ & $83.65 \mathrm{ab}$ & $8.03 a$ & $470.0 \mathrm{a}$ & $17.569 \mathrm{c}$ \\
\hline & H Soil & $67.0 \mathrm{~d}$ & $6.97 \mathrm{~b}$ & $412.3 \mathrm{c}$ & $19.419 \mathrm{~b}$ \\
\hline & H Spray & $77.37 \mathrm{c}$ & $6.20 c$ & $407.0 \mathrm{~d}$ & $17.84 \mathrm{c}$ \\
\hline & Control & $79.83 \mathrm{bc}$ & $4.43 \mathrm{e}$ & $373.7 \mathrm{f}$ & $14.95 \mathrm{f}$ \\
\hline \multirow{7}{*}{ Pioneer } & D $1.0 \mathrm{ml} / \mathrm{L}$ & 87,04 a & $7.13 c$ & $385.0 \mathrm{e}$ & $20.77 \mathrm{e}$ \\
\hline & D $1.5 \mathrm{ml} / \mathrm{L}$ & $78.79 \mathrm{~b} \mathrm{c}$ & $7.27 \mathrm{bc}$ & $402.0 \mathrm{c}$ & $19.288 \mathrm{f}$ \\
\hline & $\mathrm{E} 4.0 \mathrm{ml} / \mathrm{L}$ & $79.72 \mathrm{~b}$ & $7.80 \mathrm{~b}$ & $403.0 \mathrm{c}$ & $28.63 \mathrm{~b}$ \\
\hline & E $6.0 \mathrm{ml} / \mathrm{L}$ & $75.65 \mathrm{~cd}$ & $8.43 a$ & $438.0 \mathrm{a}$ & $29.92 \quad a$ \\
\hline & H Soil & $74.55 \mathrm{~d}$ & $7.57 \mathrm{bc}$ & $388.3 \mathrm{~d}$ & $26.797 \mathrm{C}$ \\
\hline & H Spray & $75.65 \mathrm{~cd}$ & $7.20 \mathrm{c}$ & $406.3 \mathrm{~b}$ & $24.138 \mathrm{~d}$ \\
\hline & Control & $82.35 \mathrm{~b}$ & $5.17 d$ & $306.3 \mathrm{f}$ & $19.55 \mathrm{f}$ \\
\hline & \multicolumn{5}{|c|}{ Second season: 2017} \\
\hline \multirow{7}{*}{ Hollywood } & D $1.0 \mathrm{ml} / \mathrm{L}$ & $71.94 \mathrm{~d}$ & $6.47 c$ & $412.3 \mathrm{e}$ & $18.685 \mathrm{c}$ \\
\hline & D $1.5 \mathrm{ml} / \mathrm{L}$ & 80.11 bc & $7.13 b$ & $437.7 \mathrm{c}$ & $17.75 \mathrm{~d}$ \\
\hline & $\mathrm{E} 4.0 \mathrm{ml} / \mathrm{L}$ & 85.74 a & $7.70 \mathrm{a}$ & $446.3 \mathrm{a}$ & $20.998 \mathrm{a}$ \\
\hline & $\mathrm{E} 6.0 \mathrm{ml} / \mathrm{L}$ & $81.95 \mathrm{~b}$ & 7.50ab & $440.2 \mathrm{~b}$ & $19.99 \mathrm{~b}$ \\
\hline & H Soil & $78.35 \mathrm{c}$ & $6.07 c$ & $431.0 \mathrm{~d}$ & 20.44 a \\
\hline & H Spray & $83.00 \mathrm{ab}$ & $6.23 c$ & $414.0 \mathrm{e}$ & $19.18 \mathrm{~b}$ \\
\hline & Control & 81.37 bc & $4.47 d$ & $389.3 \mathrm{f}$ & $14.58 \mathrm{e}$ \\
\hline \multirow{7}{*}{ Pioneer } & D $1.0 \mathrm{ml} / \mathrm{L}$ & 82.89 a & $6.17 d$ & $411.7 \mathrm{c}$ & $18.34 \mathrm{~d}$ \\
\hline & D $1.5 \mathrm{ml} / \mathrm{L}$ & 80.12 a-c & $6.50 \mathrm{~d}$ & $419.3 \mathrm{~b}$ & $24.47 \mathrm{c}$ \\
\hline & $\mathrm{E} 4.0 \mathrm{ml} / \mathrm{L}$ & $82.65 a b$ & $7.60 \mathrm{~b}$ & $416.0 \mathrm{~b}$ & 26.64 a \\
\hline & E $6.0 \mathrm{~cm} / \mathrm{L}$ & $79.59 \mathrm{c}$ & $8.40 a$ & $446.3 \mathrm{a}$ & $26.889 a$ \\
\hline & H Soil & 79.71 bc & $7.17 \mathrm{bc}$ & $409.7 \mathrm{c}$ & $25.46 \mathrm{~b}$ \\
\hline & H Spray & 79.59 с & $7.00 \mathrm{c}$ & $401.0 \mathrm{~d}$ & $25.71 \mathrm{~b}$ \\
\hline & Control & $78.81 \mathrm{c}$ & $4.53 e$ & $392.3 \mathrm{f}$ & $18.05 \mathrm{~d}$ \\
\hline
\end{tabular}

Means of each cultivar in each season followed by the same letter(s) are not significantly different at $5 \%$ level. D.=Daiblon K10， E.= Essential Egy ， H. = Humic acid 


\subsection{Fruit properties:-}

\subsubsection{Physical properties:}

\subsubsection{Fruit volume:}

Data in table (3) cleared that spraying Hollywood cultivar trees with Humic acid at $5 \mathrm{ml} /$ I caused the highest fruit volume compared with other treatments including control which possessed the lowest values in the two seasons. .

Regarding of Pioneer cultivar, data indicated that trees treated with Essential Egy at $4.0 \mathrm{ml} / \mathrm{I}$ and Humic acid soil application at $30 \mathrm{ml} / \mathrm{I}$ gave significantly the highest fruit size in the first season. While, trees treated with Daiblon K10 at $1.5 \mathrm{ml} / /$ obtained the best largest fruit volume in the second one compared with other treatments including control which possessed the lowest values in the two seasons.

Our results supported by the findings of, Fayeket al., (2011) who reported that spraying Le Conte pear trees with one $\mathrm{g} / \mathrm{l}$ amino acids significantly improved fruiting and fruit quality. This incensement and improvement might be attributed to enhanced pollen tube ovule penetration and delayed ovule senescence.

\subsubsection{Fruit weight:}

Data in Table (3) show that addition of Hollywood cultivar with Humic acid at $30 \mathrm{ml} / \mathrm{I}$ in the soil and spraying with Essential Egy at $4.0 \mathrm{ml} / \mathrm{l}$ treatments caused the heaviest fruit weight compared with other treatments including control which possessed the lowest values in the two seasons.

Regarding of Pioneer cultivar, data indicated that trees treated with Essential Egy at $4.0 \mathrm{ml} /$ gave significantly the highest fruit weight in the two seasons, compared with other treatments including control which possessed the lowest values in the two seasons.

Our results supported by the findings of, Naiema (2008) who reported that spraying Le Conte pear trees with Aminofert significantly increased fruit quality.

\subsubsection{Fruit length:}

Data in Table (3) show that addition of Hollywood cultivar with Humic acid at 30 $\mathrm{ml} / \mathrm{I}$ in the soil and sprayed at $5 \mathrm{ml} / \mathrm{I}$ treatments caused the highest significanlyt increase in fruit length in the first season, while in the second one Essential Egy at 4.0 $\mathrm{ml} /$ gave the best significant fruit length compared with other treatments including control which possessed the lowest values in the two seasons.

Regarding of Pioneer cultivar, data indicated that trees treated Essential Egy at $6.0 \mathrm{ml} /$ gave the greatest fruit length in the first season. Meanwhile, in the second season trees treated with Daiblon $\mathrm{K} 10$ at $1.5 \mathrm{ml} /$; Essential Egy at $4.0 \mathrm{ml} / \mathrm{l}$ and Humic acid spraying gave the best significant results compared with other treatments including control which possessed the lowest values in the two seasons.

These results are in harmony with the results found by Mouco et al., (2009) who found that spraying mango trees with amino acids increased panicle length. There 
were no statistical differences among amino acid concentrations i.e. $(0.0,0.02,0.04$ and $0.06 \%$ ) regarding panicle length.

\subsubsection{Fruit diameter:}

Data in Table (3) showed that application of Hollywood cultivar, Humic acid in the soil at $30 \mathrm{ml} / /$ caused the highest fruit diameter with other treatments including control which possessed the lowest values in the two seasons.

Regarding of pioneer cultivar, data indicated that trees addition with Humic acid at $30 \mathrm{ml} / \mathrm{I}$ in the soil recorded the best significant fruit diameter compared with other treatments including control which possessed the lowest values in the two seasons..

In harmony with these results, Maklad and Ismaile (2016) stated that Pioneer plum cultivar has good fruit quality properties.

Table 3. Fruit physical properties of the two plum cultivars as affected by different stimulants in 2016 and 2017 seasons.

\begin{tabular}{|c|c|c|c|c|c|}
\hline \multirow{3}{*}{ Cultivar } & \multirow{3}{*}{ Treatments } & \multicolumn{4}{|c|}{ Fist season: 2016} \\
\hline & & \multicolumn{4}{|c|}{ Fruit parameters } \\
\hline & & $\begin{array}{c}\text { Fruit } \\
\text { Volume }\left(\mathrm{cm}^{3}\right) \\
\end{array}$ & $\begin{array}{c}\text { Fruit } \\
\text { Weight(g) }\end{array}$ & $\begin{array}{c}\text { Fruit Length } \\
(\mathbf{c m})\end{array}$ & $\begin{array}{c}\text { Fruit Diameter } \\
(\mathbf{c m})\end{array}$ \\
\hline \multirow{7}{*}{ Hollywood } & D $1.0 \mathrm{ml} / \mathrm{L}$ & $45.75 c$ & 39.70 de & $4.10 \mathrm{bc}$ & $4.30 \mathrm{~b}$ \\
\hline & $\mathrm{D} 1.5 \mathrm{ml} / \mathrm{L}$ & $44.00 \mathrm{c}$ & $36.79 \mathrm{f}$ & $4.00 \mathrm{~cd}$ & $4.03 c$ \\
\hline & $\mathrm{E} 4.0 \mathrm{ml} / \mathrm{L}$ & $51.75 \mathrm{~b}$ & $44.05 \mathrm{~b}$ & $4.23 a b$ & $4.38 \mathrm{~b}$ \\
\hline & $\mathrm{E} 6.0 \mathrm{ml} / \mathrm{L}$ & $40.83 d$ & 37.38 ef & $4.25 a b$ & $4.38 b$ \\
\hline & H Soil & $52.25 b$ & $47.01 \mathrm{a}$ & $4.40 a$ & $4.60 a$ \\
\hline & H Spray & $61.75 a$ & 43.83 bc & $4.33 a$ & $4.25 b$ \\
\hline & Control & $40.00 \mathrm{~d}$ & $40.0 \mathrm{~d}$ & 3.90d & $3.95 c$ \\
\hline \multirow{7}{*}{ Pioneer } & $\mathrm{D} 1.0 \mathrm{ml} / \mathrm{L}$ & $50.50 \mathrm{~d}$ & $53.94 \mathrm{f}$ & $4.33 d$ & $4.43 d$ \\
\hline & $\mathrm{D} 1.5 \mathrm{ml} / \mathrm{L}$ & $53.75 \mathrm{~cd}$ & $47.98 \mathrm{~g}$ & $4.35 d$ & $4.4 d$ \\
\hline & $\mathrm{E} 4.0 \mathrm{ml} / \mathrm{L}$ & $84 ., 00 a$ & $71.03 \mathrm{a}$ & $4.83 a b$ & $5.50 a$ \\
\hline & $\mathrm{E} 6.0 \mathrm{ml} / \mathrm{L}$ & $72.25 b$ & $68.31 \mathrm{c}$ & $4.98 a$ & $5.13 \mathrm{~b}$ \\
\hline & H Soil & $84.00 a$ & $69.01 \mathrm{bc}$ & $4.78 \mathrm{~b}$ & $5.45 a$ \\
\hline & H Spray & $70.25 b$ & $59.41 \mathrm{e}$ & $4.43 \mathrm{~cd}$ & $4.85 c$ \\
\hline & Control & $57.25 \mathrm{c}$ & $63.83 \mathrm{~d}$ & $4.55 c$ & $4.80 c$ \\
\hline \multicolumn{6}{|c|}{ Second season: 2017} \\
\hline \multirow{7}{*}{ Hollywood } & $\mathrm{D} 1.0 \mathrm{ml} / \mathrm{L}$ & $45.30 \mathrm{~b}$ & $45.32 \mathrm{~b}$ & $4.13 b c$ & 4.38a \\
\hline & $\mathrm{D} 1.5 \mathrm{ml} / \mathrm{L}$ & $44.00 \mathrm{~b}$ & $40.56 \mathrm{c}$ & $4.13 \mathrm{bc}$ & $4.15 b$ \\
\hline & E $4.0 \mathrm{ml} / \mathrm{L}$ & $51.05 \mathrm{~b}$ & $47.05 \mathrm{a}$ & $4.43 a$ & 4.33a \\
\hline & $\mathrm{E} 6.0 \mathrm{ml} / \mathrm{L}$ & $43.63 \mathrm{~b}$ & $45.43 \mathrm{~b}$ & $4.05 c$ & $4.18 b$ \\
\hline & H Soil & $50.50 a$ & $47.43 \mathrm{a}$ & $4.23 b$ & $4.38 a$ \\
\hline & H Spray & $49.25 a$ & $46.33 \mathrm{~b}$ & $4.20 \mathrm{bc}$ & 4.35a \\
\hline & Control & $39.20 c$ & $37.45 \mathrm{~d}$ & $3.80 \mathrm{~d}$ & $3.85 c$ \\
\hline \multirow{7}{*}{ Pioneer } & D $1.0 \mathrm{ml} / \mathrm{L}$ & $59.33 b$ & $44.55 \mathrm{e}$ & $4.23 b$ & $4.40 c$ \\
\hline & $\mathrm{D} 1.5 \mathrm{ml} / \mathrm{L}$ & $76.00 \mathrm{a}$ & $58.36 \mathrm{~d}$ & $4.68 a$ & $4.40 c$ \\
\hline & $\mathrm{E} 4.0 \mathrm{ml} / \mathrm{L}$ & $47.75 d$ & $64.02 \mathrm{a}$ & $4.50 a$ & $4.38 c$ \\
\hline & $\mathrm{E} 6.0 \mathrm{ml} / \mathrm{L}$ & $45.75 d$ & $60.25 \mathrm{c}$ & $3.90 c$ & $4.35 c$ \\
\hline & H Soil & $55.50 \mathrm{c}$ & $62.14 \mathrm{~b}$ & $4.25 b$ & $5.33 a$ \\
\hline & H Spray & $61.75 b$ & $64.12 \mathrm{a}$ & $4.53 a$ & $4.75 b$ \\
\hline & Control & $52.00 \mathrm{c}$ & $46.01 \mathrm{e}$ & $4.28 b$ & $4.88 b$ \\
\hline
\end{tabular}

Means of each cultivar in each season followed by the same letter(s) are not significantly different at $5 \%$ level. D.=Daiblon K10， E.= Essential Egy ， H. = Humic acid 


\subsubsection{Fruit firmness: -}

Data in Table (4) showed that Essential Egy at $4.0 \mathrm{ml} /$ / gave the highest significant firmness values with Hollywood and Pinoeer cultivars compared with other treatments including control which gained the lowest values in the two seasons

In this respect, Hassan et al., (2010) postulated that Aminofert increased significantly the firmness of Hollywood plum fruits as compared to the control.

\subsubsection{Chemical properties: -}

\subsubsection{Juice Soluble solids content (SSC):}

Data in table (4) showed that spraying trees of Hollywood cultivar by Daiblon K10 at $1.5 \mathrm{ml} /$; Essential Egy at 4.0 and $6.0 \mathrm{ml} / /$ recorded the highest juice soluble solid content (SSC) values in the first season compared with other treatments and control which recorded the lowest values in the first season and Humic acid in the second one.

With regard to Pioneer cultivar, spraying trees with Essential Egy at $4.0 \mathrm{ml} / /$ gave the best values of SSC in comparison with other treatments including control which recorded the lowest values in the two seasons.

In this respect, Hassan et al., (2010) mentioned that spraying trees with Aminofert increased significantly T.S.S in Hollywood plum fruits as compared to the control.

\subsubsection{Titratable acidity:}

Data in table (4) showed that in Hollywood cultivar, the lowest significant values of total acidity \% were recorded with Daiblon $\mathrm{k} 10$ at $1.5 \mathrm{ml} / \mathrm{l}$; Essential Egy at $4.0 \mathrm{ml} / \mathrm{l}$ and control treatments in the first season. Humic acid spraying and control treatments gave the minimum significant acidity \% in the second season.

With regard to Pioneer cultivar, the lowest significant total acidity $\%$ was recorded with Essential Egy at 4.0 and $6.0 \mathrm{ml} / \mathrm{l}$ and Humic acid soil application treatments in the first season. Essential Egy at $4.0 \mathrm{ml} / \mathrm{l}$; Humic acid soil application and control treatments gave the minimum significant total acidity \% in the second season.

These results are in agreement with Hassan et al., (2010) reported that spraying Hollywood trees with Aminofert increased significantly acidity in Hollywood plum fruits as compared to the control. Likewise, Naiema (2008) stated that Aminofert increased significantly acidity on Le Conte pear trees.

\subsubsection{SSC / TA ratio:}

Data in table (4) indicated that, spraying Hollywood trees with Daiblon k10 at $1.5 \mathrm{ml} /$ / significantly increased SSC / TA ratio of Hollywood cultivar in the two seasons. While the lowest values were obtained when trees were treated with either Daiblon at $1.0 \mathrm{ml} / \mathrm{I}$, Humic acid $5 \mathrm{ml} / /$ or control. 
With regard to Pioneer cultivar, the highest values were obtained when trees were treated with Essential Egy with the two concentrations in the first season. While, control treated possessed was the highest values in the second one.

In this respect, Hassan et al., (2010) found that Aminofert improved acidity as compared to the control on Hollywood plum cultivar.

Table 4. Fruit firmness and some chemical properties of two plum cultivars as affected by different stimulants in 2016 and 2017 seasons.

\begin{tabular}{|c|c|c|c|c|c|}
\hline \multirow{3}{*}{ Cultivar } & \multirow{3}{*}{ Treatments } & \multicolumn{4}{|c|}{ First season: 2016} \\
\hline & & \multicolumn{4}{|c|}{ Chemical Fruit parameters } \\
\hline & & $\begin{array}{l}\text { Fruit firmness } \\
\left.\text { (Ib / Inch }{ }^{2}\right)\end{array}$ & $\begin{array}{l}\text { SSC } \\
(\%)\end{array}$ & $\begin{array}{c}\text { Acidity } \\
(\%)\end{array}$ & $\begin{array}{c}\text { SSC / acidity } \\
\text { ratio }\end{array}$ \\
\hline \multirow{7}{*}{ Hollywood } & D $1.0 \mathrm{ml} / \mathrm{L}$ & $9.88 \mathrm{~d}$ & $9.25 \mathrm{~b}$ & $0.86 a b$ & $10.74 \mathrm{~d}$ \\
\hline & $\mathrm{D} 1.5 \mathrm{ml} / \mathrm{L}$ & $10.45 \mathrm{c}$ & $10.30 \mathrm{a}$ & $0.58 \mathrm{c}$ & $17.76 \mathrm{a}$ \\
\hline & $\mathrm{E} 4.0 \mathrm{ml} / \mathrm{L}$ & $12.05 \mathrm{a}$ & $10.30 \mathrm{a}$ & $0.65 \mathrm{c}$ & $15.99 \mathrm{~b}$ \\
\hline & $\mathrm{E} 6.0 \mathrm{ml} / \mathrm{L}$ & $10.32 \mathrm{c}$ & $10.25 \mathrm{a}$ & $0.81 \mathrm{ab}$ & $12.73 \mathrm{c}$ \\
\hline & H Soil & $11.25 \mathrm{~b}$ & $6.25 \mathrm{e}$ & $0.90 \mathrm{a}$ & $7.11 \mathrm{e}$ \\
\hline & H Spray & $10.88 \mathrm{~b}$ & $7.85 \mathrm{c}$ & $0.78 \mathrm{~b}$ & $10.43 \mathrm{~d}$ \\
\hline & Control & $10.55 \mathrm{c}$ & $6.95 \mathrm{~d}$ & $0.66 \mathrm{c}$ & $10.06 \mathrm{~d}$ \\
\hline \multirow{7}{*}{ Pioneer } & D $1.0 \mathrm{ml} / \mathrm{L}$ & $8.38 \mathrm{ab}$ & $10.27 \mathrm{~b}$ & $0.60 \mathrm{~b}$ & $17.36 \mathrm{~b}$ \\
\hline & D $1.5 \mathrm{ml} / \mathrm{L}$ & $8.00 a b$ & $10.25 b$ & 0.79 a & $13.15 \mathrm{c}$ \\
\hline & $\mathrm{E} 4.0 \mathrm{ml} / \mathrm{L}$ & $9.28 \mathrm{a}$ & $10.65 \mathrm{a}$ & $0.49 \mathrm{c}$ & $21.65 \mathrm{a}$ \\
\hline & $\mathrm{E} 6.0 \mathrm{ml} / \mathrm{L}$ & $7.83 a b$ & $10.45 a b$ & $0.52 \mathrm{c}$ & 20.31 a \\
\hline & H Soil & $8.20 \mathrm{ab}$ & $9.23 \mathrm{c}$ & $0.50 \mathrm{c}$ & $18.68 \mathrm{~b}$ \\
\hline & H Spray & $8.73 a b$ & $10.75 \mathrm{a}$ & $0.83 \mathrm{a}$ & $12.96 \mathrm{c}$ \\
\hline & Control & $9.31 \mathrm{a}$ & $9.00 c$ & $0.49 \mathrm{c}$ & $18.75 \mathrm{~b}$ \\
\hline \multicolumn{6}{|c|}{ Second season: 2017} \\
\hline \multirow{7}{*}{ Hollywood } & D $1.0 \mathrm{ml} / \mathrm{L}$ & $10.07 \mathrm{~cd}$ & $10.23 \mathrm{~b}$ & $0.80 \mathrm{ab}$ & $12.79 \mathrm{ab}$ \\
\hline & D $1.5 \mathrm{ml} / \mathrm{L}$ & $10.63 \mathrm{~b}$ & $10.73 \mathrm{a}$ & $0.81 \mathrm{a}$ & $13.26 \mathrm{a}$ \\
\hline & $\mathrm{E} 4.0 \mathrm{ml} / \mathrm{L}$ & $11.60 \mathrm{a}$ & $9.10 \mathrm{c}$ & $0.81 \mathrm{a}$ & $11.21 \mathrm{c}$ \\
\hline & $\mathrm{E} 6.0 \mathrm{ml} / \mathrm{L}$ & $9.78 \mathrm{~d}$ & $10.50 \mathrm{a}$ & $0.84 a$ & $12.53 \mathrm{~b}$ \\
\hline & H Soil & $10.82 \mathrm{~b}$ & $6.28 \mathrm{e}$ & $0.84 a$ & $7.54 \mathrm{e}$ \\
\hline & H Spray & 10.50 be & $7.28 \mathrm{~d}$ & $0.74 \mathrm{bc}$ & $9.94 \mathrm{~d}$ \\
\hline & Control & $10.12 \mathrm{c}$ & $7.18 \mathrm{~d}$ & $0.72 \mathrm{c}$ & $10.05 \mathrm{~d}$ \\
\hline \multirow{7}{*}{ Pioneer } & D $1.0 \mathrm{ml} / \mathrm{L}$ & $7.38 \mathrm{~cd}$ & $10.30 \mathrm{ab}$ & $0.62 \mathrm{~b}$ & $16.73 \mathrm{c}$ \\
\hline & D $1.5 \mathrm{ml} / \mathrm{L}$ & $7.95 a b$ & $9.68 \mathrm{c}$ & $0.59 \mathrm{bc}$ & $16.54 \mathrm{c}$ \\
\hline & $\mathrm{E} 4.0 \mathrm{ml} / \mathrm{L}$ & $8.25 \mathrm{a}$ & $10.58 \mathrm{a}$ & $0.52 \mathrm{~d}$ & $20.64 \mathrm{~b}$ \\
\hline & $\mathrm{E} 6.0 \mathrm{ml} / \mathrm{L}$ & $7.65 \mathrm{bc}$ & $10.00 \mathrm{bc}$ & $0.58 \mathrm{bc}$ & $17.44 \mathrm{C}$ \\
\hline & H Soil & $8.08 a b$ & $9.00 \mathrm{~d}$ & $0.55 \mathrm{~cd}$ & $16.37 \mathrm{c}$ \\
\hline & H Spray & $7.63 \mathrm{bc}$ & $8.60 \mathrm{~d}$ & $0.75 \mathrm{a}$ & $11.52 \mathrm{~d}$ \\
\hline & Control & $7.01 \mathrm{~d}$ & $8.88 \mathrm{~d}$ & $0.39 \mathrm{e}$ & $22.77 \mathrm{a}$ \\
\hline
\end{tabular}

Means of each cultivar in each season followed by the same letter(s) are not significantly different at $5 \%$ level. D.=Daiblon K10, 


\subsection{Vegetative growth :-}

\subsubsection{Leaf total chlorophyll contest:}

Data in table (5) cleared that, Essential Egy at $4.0 \mathrm{ml} / \mathrm{l}$ and Humic acid soil application significantly increased total chlorophyll of Hollywood cultivar.

With Pioneer cultivar, Daiblon $\mathrm{K} 10$ at $1.0 \mathrm{ml} / \mathrm{l}$ and Essential Egy at $4.0 \mathrm{ml} / \mathrm{l}$ had the best significant results.

Our results are in agreement with, Zewail, (2014) on beanwho indicated that , foliar spray of seaweed ( $\mathrm{Fe}, \mathrm{N}, \mathrm{Cu}, \mathrm{Mn}$, Mo, vitamins, enzymes, amino acids, sugars and plant hormones) and amino acids three times on bean increased photosynthetic pigments and total chlorophyll . He added also that, the most effective treatments were that of seaweed at $2 \mathrm{ml} / \mathrm{I}$ combined with the amino acids at $4 \mathrm{ml} / \mathrm{l}$.

\subsubsection{Chemical determination:-}

\subsubsection{Leaf nitrogen (\%):}

With Hollywood cultivar, Daiblon $\mathrm{K} 10$ at $1.5 \mathrm{ml} / \mathrm{l}$ and Humic acid spray treatment produced the highest significant nitrogen percentage, while Essential Egy treatment at $4.0 \mathrm{ml} /$ I recorded the lowest significantly value.

With Pioneer cultivar, Humic acid soil application and spray treatments gave the highest significant nitrogen\%. Essential Egy at $4.0 \mathrm{ml} / \mathrm{l}$ and control treatments had the lowest significantly value.

\subsubsection{Leaf phosphorus (\%):}

With Hollywood cultivar, Daiblon $\mathrm{K} 10$ at $1.5 \mathrm{ml} / \mathrm{l}$ treatment recorded the highest phosphorus percentage. But, Essential Egy at $6.0 \mathrm{ml} / \mathrm{l}$; Humic acid soil application and spray treatments gave the lowest significant values.

With Pioneer cultivar, Essential Egy at $4.0 \mathrm{ml} / \mathrm{l}$ and $6.0 \mathrm{ml} / \mathrm{l}$ and Humic acid soil application treatments recorded the highest significant phosphorus percentage. Meanwhile, Daiblon $\mathrm{K} 10$ at $1.5 \mathrm{ml} / \mathrm{l}$ treatment gave the lowest significant value.

\subsubsection{Leaf potassium (\%):-}

With Hollywood cultivar, Humic acid spray treatment gave the highest significant potassium percentage, whereas, Daiblon $\mathrm{k} 10$ at $1.0 \mathrm{ml} / \mathrm{l}$ and $1.5 \mathrm{~cm} / \mathrm{l}$ and Essential Egy at $0.6 \mathrm{ml} / \mathrm{l}$ recorded the lowest significant value.

With Pioneer cultivar, Humic acid spray treatment obtained the highest significant potassium \%. Meanwhile, Daiblon $\mathrm{k} 10$ at $1.0 \mathrm{ml} / \mathrm{l}$ treatment stated the lowest significantly value.

These results are in agreement with those obtained by Asik et al., (2009) who reported that soil application of humus increased the $\mathrm{N}$ uptake in wheat. 
Meanwhile, foliar application of humic acid increased the uptake of $\mathrm{P}, \mathrm{K}, \mathrm{Mg}, \mathrm{Na}$, $\mathrm{Cu}$ and Zn. Nevertheless, Hassan et al., (2010) declared that Aminofert applied to foliage caused a pronounced increase in leaf $\mathrm{N}$ and $\mathrm{K}$ content, while leaf $\mathrm{P}$ content decreased in both experimental seasons. Similarly, Naiema (2008) found that Aminofert increased significantly total sugar and some leaf mineral $\mathrm{N}$, while leaf $\mathrm{P}$ content decreased in Le Conte pear trees.

Table 5. Average Total chlorophyll , N, P and K leaf contents of two plum cultivars as affected by different stimulants in 2016 and 2017 seasons.

\begin{tabular}{|c|c|c|c|c|c|}
\hline \multirow[b]{2}{*}{ Cultivar } & \multirow[b]{2}{*}{ Treatments } & \multicolumn{4}{|c|}{$\begin{array}{c}\text { Total chlorophyll and Chemical determination in Leaves (as } \\
\text { average of the two seasons) }\end{array}$} \\
\hline & & $\begin{array}{c}\text { Total chlorophyll } \\
\text { content in } \\
\text { leaves }\end{array}$ & $\begin{array}{c}\text { Nitrogen } \\
(\%)\end{array}$ & $\begin{array}{c}\text { Phosphorus } \\
(\%)\end{array}$ & $\begin{array}{c}\text { Potassium } \\
\text { (\%) }\end{array}$ \\
\hline \multirow{7}{*}{ Hollywood } & D $1.0 \mathrm{ml} / \mathrm{L}$ & $42.93 \mathrm{a}-\mathrm{c}$ & $3.667 \mathrm{~d}$ & $0.233 \mathrm{c}$ & $1.136 \mathrm{e}$ \\
\hline & D $1.5 \mathrm{ml} / \mathrm{L}$ & 41.18 bc & $4.448 a$ & $0.506 a$ & $1.137 \mathrm{e}$ \\
\hline & $\mathrm{E} 4.0 \mathrm{ml} / \mathrm{L}$ & $41.70 a b$ & $2.966 \mathrm{f}$ & $0.313 b$ & $1.174 \mathrm{~d}$ \\
\hline & E $6.0 \mathrm{ml} / \mathrm{L}$ & 42.98 a-d & $4.145 b$ & $0.194 \mathrm{~d}$ & $1.152 \mathrm{de}$ \\
\hline & H Soil & $42.28 a b$ & $3.861 \mathrm{c}$ & $0.207 \mathrm{~d}$ & $1.244 \mathrm{~b}$ \\
\hline & H Spray & 4223 a-c & $4.347 a$ & $0.202 \mathrm{~d}$ & $1.287 \mathrm{a}$ \\
\hline & Control & 93.65 c-e & $3.321 \mathrm{e}$ & $0.125 \mathrm{e}$ & $1.209 \mathrm{C}$ \\
\hline \multirow{7}{*}{ Pioneer } & D $1.0 \mathrm{ml} / \mathrm{L}$ & $40.05 a$ & $3.934 \mathrm{~b}$ & $0.363 \mathrm{~b}$ & $0.234 \mathrm{~g}$ \\
\hline & D $1.5 \mathrm{ml} / \mathrm{L}$ & $34.25 b$ & $3.733 \mathrm{~b}$ & $0.273 \mathrm{~d}$ & $0.284 \mathrm{f}$ \\
\hline & $\mathrm{E} 4.0 \mathrm{ml} / \mathrm{L}$ & $40.20 \mathrm{a}-\mathrm{c}$ & $2.999 \mathrm{~d}$ & $0.385 a$ & $1.195 \mathrm{~d}$ \\
\hline & E $6.0 \mathrm{ml} / \mathrm{L}$ & 34.13 bc & $3.256 \mathrm{c}$ & $0.395 \mathrm{a}$ & $1.315 \mathrm{~b}$ \\
\hline & H Soil & 30.53 c-e & $4.859 a$ & $0.386 a$ & $1.276 \mathrm{c}$ \\
\hline & H Spray & $34.65 \mathrm{~b}-\mathrm{d}$ & $4.857 \mathrm{a}$ & $0.246 \mathrm{e}$ & $1.407 \mathrm{a}$ \\
\hline & Control & $24.30 \mathrm{de}$ & $3.054 \mathrm{~cd}$ & 0.292 c & $1.076 \mathrm{e}$ \\
\hline
\end{tabular}

Means of each of cultivars in each season followed by the same letter(s) are not significantly different at 5\% level. D.=Daiblon K10， E. $=$ Essential Egy ， H. = Humic acid

\section{CONCLUSION}

From the above obtained results, it can be recommend that, spraying Hollywood and Pioneer trees with Essential Egy at either $4.0 \mathrm{ml} / \mathrm{l}$ or $6.0 \mathrm{ml} / \mathrm{l}$ three times at $30 \%$; at $70 \%$ of flowering and at the full bloom)are promising treatments that can to increase yield and improve fruit properties at harvest under similar conditions. 


\section{REFERENCES}

1. Abd Elaziz, Y.S.G.; Shakweer, N.H. and El-Hadidy, G.A.M. 2017. Evaluation of Pioneer and Hollywood plum cultivars under sandy soil conditions in Egypt. Bull. Fac. Agric. Cairo Univ., 68: 411-424.

2. Alva, A.K. and obreza,T.A. 1998. By-product iron-humateincreases tree growth and fruit production of orange and grapefruit, Hortscience, 33 (1) : $71-74$.

3. A.O.A.C. \{Association of official Agriculture chemists\} 1990. Official methods of analysis 15 th Ed., Washington D.C., USA.

4. Asik, B.B.; Turan, M.A.;Celik, H. and Katkat A.V. 2009. Effects of humic substances on plant growth and mineral nutrients uptake of wheat (Triticumdurum cv. Salihli) under conditions of salinity. Asian Journal of crop science, 1: 87 - 95 .

5. Chen, Y.; Magen, H. and Riov, J. 1994. Humic substances originating from rapidly decomposing organic matter. Proc. Int. meet. $6{ }^{\text {th }}$ sep.1992 : 427 - 443. (c.a. chem.Abst. $121: 229$ ).

6. Duncan, D. B. 1955. Multiple ranges and multiple tests. Biometrics, 11: 1 - 24.

7. Fayed, T.A. 2010. Optimizing yield, fruit quality and nutration status of Roghiani olives grown in libia using some organic extracts.J. Hort. Sci. and ornament. Plants, 2: $63-78$.

8. Fayek, M. A.; YehiamT. A.; El-Fakhrany,E.M.M. and Farray, A.M. 2011. Effect of ringing and Amino acids application on improving fruiting of le Conte pear trees. Journal of Horticultural science \&Ornamental plants 3(1):01-10

9. Franco - Mora, O.; Tanabe, K.; Tamura, F. and Itai, A. 2005. Effect of putrescine application on fruit set in Housui Japanese pear (Pyrus pyrifoliaNakai). Sci. Hort. 104: $265-273$.

10. Hassan, H.S.A.; Sarrwy, S.M.A. and Mostafa, E.A.M. 2010. Effect of foliar spraying with liquid organic fertilizer, some micro - nutrients and gibberellins on leaf mineral content, fruit set, yield and fruit quality of Hollywood plum trees. Agriculture and biology Journal of North America ISSN print : 2151 - 7517.

11. Jackson, N.L. 1958. Soil chemical Analysis. Constable. Ltd. Co., London pp. 498.

12. Laure, J.H. and Hofson, R.S. 1989. Peaches, plums and nectarines growing and handling for fresh market. Copyright the Regent of the Univ. of Calif., Division of Agric. And Natural Resources pub. 3331: $74-81$.

13. Maklad, M.F. and Ismaile,S. A. 2016. Evaluation of pioneer and celebration plum cultivars under El - Khatatba region condition. J.plant production, Mansoura Univ., vol. 7 (7): 763-767. 
14. Mouco, M.A.do. C.; Lima, M.A.C. de; Silva, A.L. da; Santos, S.C.A. dos and Rodrigues, F.M. 2009. Amino acids on mango yield and fruit quality at submedioSao fracisco Region, Brazil.ActaHorticulturae. (820): 437-442.12 ref. Egypt.

15. Naiema, M.S.M. 2008. Effect of foliar application of liquid organic fertilizer (Aminofert), some micro nutrients and Gibberellin on leaf mineral content, fruit set, yield and fruit quality of le - Conte peer trees. Alexandria Journal of Agricultural Research 53 (1): 63 - 71.34 ref. Egypt.

16. Opike, H. and Rolfe, S. 2005.The physiology of flowering plants.Cambridge Univ. pres 5. Plant Growth hormones pp: $177-194$.

17. Piper, C.S. 1950. Soil and plant analysis. Inter. Sci., pulb, New York, pp. 368.

18. Plummer, D.T. 1971).An introduction to practical biochem.Published by McGraw Hill Book Company (u.k) limited.

19. Shahin, M.F.M. ;Genaidy, E.A.E and Laila, F. Haggag. 2015. Impact of amino acids, Vinasse and Humic acid as soil application on fruit quality and quantity of "Kalamata" olive trees. International Journal of chemTech Research vol. 8, No. 11 pp. $75-84$.

20. Snedecor, G.W. and Cochran, W.G. 1990. Statistical methods. Oxford and J.B.H. publishing com. 7 th edition.

21. Swietlik, D. 1991. Growth of four citrus rootstocks treated with a natural biostimulant. Subtropical plant Sci., 44: $11-14$.

22. Westwood, M.N., 1993. Temperate zone pomology, physiology and culture. Third Edition Himber press Portland, Oregon, p. 523.

23.Yadava, Y.L. 1986. A rapid and non - destructive method to determine chlorophyll in intact leaves. Hort. Science, 12: $1449-1450$.

24. Zewail, R. M. T. 2014. Effect of seaweed extract and amino acids on growth and productivity and some bioconstituents of common bean (Phaseolus vulgaris I.) plants production, Mansoura Univ . vol. 5 (8): 1441 - 1453. 


\title{
تأثير بعض محفزات النمو على نسبة العقد والمحصول وصفات جودة ثمار صنفي البرقوق هوليود وبايونير
}

\author{
عزة إبر اهيم محمد، أشرف عبد البارئ، مصطقى احمد فتحى \\ قسم بحوث الفاكهة المتساقطة الأوراق - معهد بحوث البساتين - مركز البحوث الزراعية - مصر.

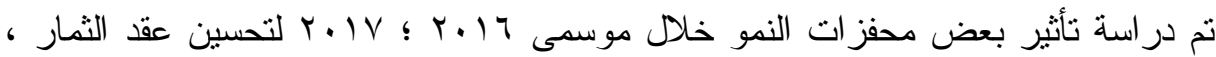

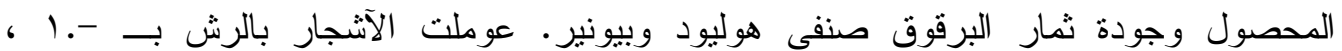

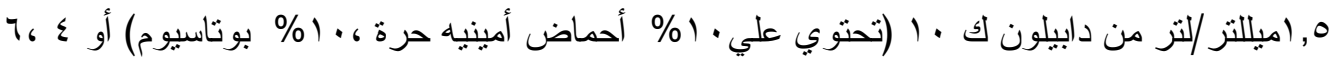

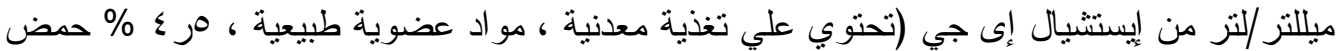

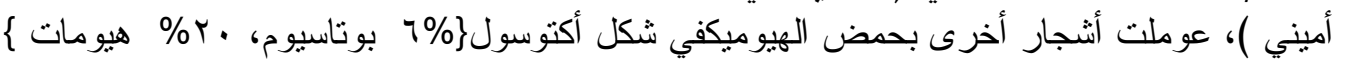

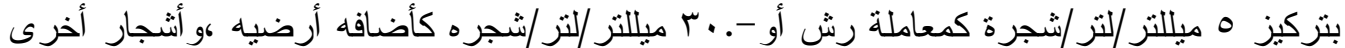

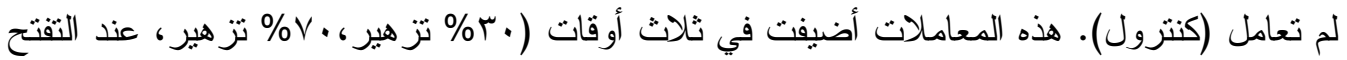

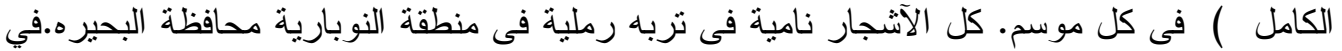 \\ تصميم عشوائي كامل فىى مكررات، وقد أخذت القياسات التاليه:- النسبة المئويه لعقد

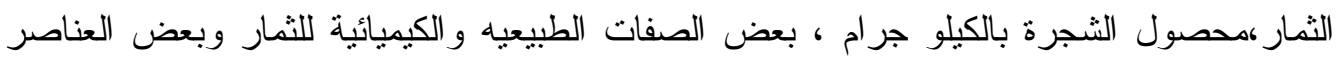

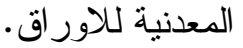

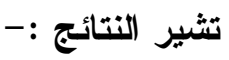

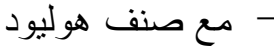

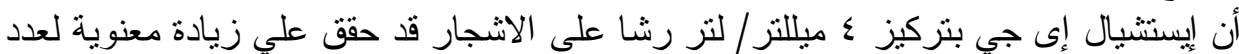

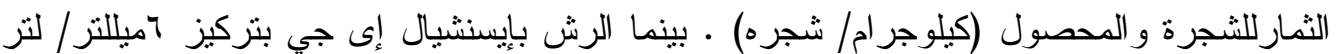

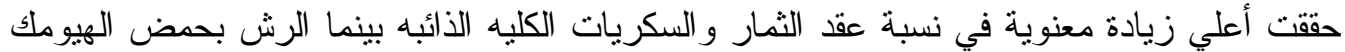

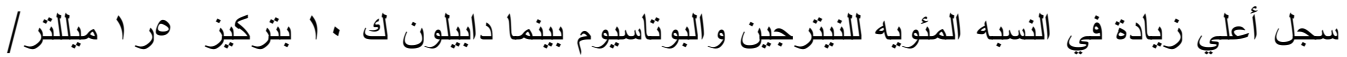
لتر أعطت أعلي زيادة معنويه في السكريات الكلية الذائبة و النسبة المئوية للنيترجين و الفسفور · ل كل

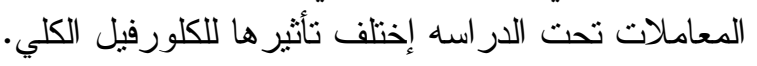

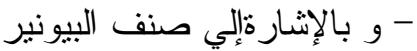

وجد أن إسينشيال إى جي بتركيز آميللتز/ لتر أعطى أعلي زيادة معنوية لنسبة العقد وعدد

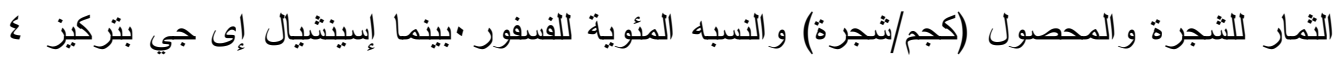
ميللتر / لتر أعطى أعلي زيادة معنوية فى السكريات الكلية الذائبة و النسبة المئوية للفسفور • بينما الإضافه الآرضيه لحمض الهيوميك أعطى أعلي زيادة للنسبة المئوية للنيتروجين و الفسفور بينما

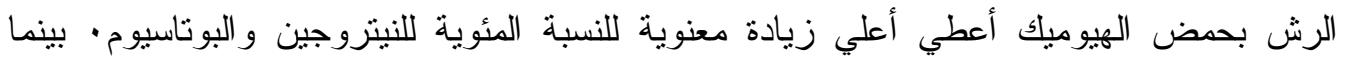

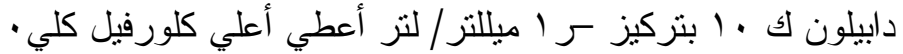
التوصية ألتية

يمكن التوصية بمعاملة أثجار البرقوق صنفى هوليود و البيونيررشا بإيسنشيال إى جي

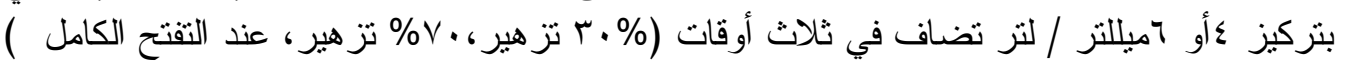
لزيادة المحصول وتحسين صفات الثمار عند الحصاد. 